\section{Climate Change Literacy in Postsecondary Horticultural Education in the United States}

\author{
Virginia I. Lohr ${ }^{1}$
}

\begin{abstract}
AdDitional INDEX wORDs. curriculum, global warming, instruction, land-grant universities, undergraduate education

SumMARY. Horticultural crops are being affected by weather extremes consistent with predictions from climate change models. Impacts include crop losses and extended growing seasons. Negative effects on crop productivity are predicted to vastly overwhelm any positive effects. Students who graduate from our programs will need additional knowledge to succeed compared with those trained in previous decades. To determine the extent to which higher educational institutions across the United States are educating students about these issues, a survey was conducted to gather information on the incorporation of climate change literacy in horticultural curricula. Most programs do not currently offer classes with "climate change" or "global warming" in the formal title or description, but many instructors are including at least some information related to climate change in specific courses they teach. Instructors of courses in fruits, vegetables, or turf, and instructors who do not teach at 1862 land-grant universities, are more likely than other instructors to include content related to climate change in their courses. Instructors who do not have tenure and instructors who teach plant identification courses are more likely than other instructors to have increased the content on climate change in their classes over time.
\end{abstract}

A ccording to a recent report by the U.S. Department of Agriculture (USDA), "Climate change poses unprecedented challenges to U.S. agriculture because of the sensitivity of agricultural productivity and costs to changing climate conditions" (Walthall et al., 2013 ). Factors that may adversely affect productivity include rising nighttime temperatures, changes in precipitation patterns, reductions in pollination, and loss of chilling requirements. According to this recent report, changes such as these will outweigh increases in plant growth from elevated levels of atmospheric carbon dioxide. Such unprecedented challenges to agriculture from climate change will likely present unprecedented challenges to those teaching students about agriculture.

Weather extremes consistent with predictions from climate change and global warming models are already occurring. For example, the U.S. Environmental Protection Agency (EPA) reports that the growing season in the 48 contiguous U.S. states has been above the long-term average every year since 1980 and is now about 2 weeks longer than in 1900 (EPA,

Department of Horticulture, Washington State University, Pullman, WA 99164-6414

${ }^{1}$ Corresponding author. E-mail: lohr@wsu.edu. 2013a). Although much of country is experiencing longer growing seasons, parts of the country have experienced hard, damaging freezes later in the spring than previously (Augspurger, 2013; Marino et al., 2011). The number and severity of extreme precipitation events have also increased (Booth et al., 2012). Parts of the country are becoming wetter, whereas others are becoming drier (EPA, 2013b). Changes are prevalent worldwide (Battisti and Naylor, 2009). These are already impacting horticulture, with crop failures and rising prices evident (Lyall, 2013; McGowan, 2013). Weather extremes will become more frequent and destructive if global temperatures rise as rapidly and as high as the models currently predict (Karl et al., 2009).

The American Association for the Advancement of Science (AAAS), the National Oceanic and Atmospheric Administration (NOAA), and other scientific groups have expressed a critical need for climate literacy among individuals and communities (U.S. Global Change Research Program, 2009). These organizations helped to develop a climate literacy brochure; it points out that changes from global warming "will affect almost every aspect of human society, including economic prosperity, human and environmental health, and national security" (U.S. Global Change Research
Program, 2009). Other notable points in the brochure include the importance of having climate-literate individuals to help prepare for and act to address the unprecedented challenges of climate change, such as by "planting new crops that will thrive under new climate conditions" (U.S. Global Change Research Program, 2009). In Apr. 2013, the National Research Council, the National Science Teachers Association, AAAS, and Achieve released a new set of K-12 science standards that included climate literacy (Achieve, 2013). By the end of Oct. 2013, these standards had already been adopted by seven states.

The extent to which postsecondary institutions are including climate literacy in horticultural curricula and preparing future horticulturists for the challenges of climate change is unknown, but the inclusion of climate change in horticultural curricula appears to be a recent phenomenon. In 2009, climate change was not included in a consensus list of suggested competencies for horticulture students receiving bachelor's degrees in the United States (Basinger et al., 2009), but it was included in a similar list published in 2013 (Pritts and Park, 2013). Sources of information on climate change that can be used in our classes abound, but specific examples of how or what to incorporate in horticultural curricula are harder to find. NOAA (2013) and EPA (2013c) have climate change sections on their websites that include summary statistics along with short explanations and clear graphics that can be downloaded. The USA National Phenology Network (2013) has a section with resources for higher education. Presentations given at conferences of the American Society for Horticultural Sciences related to climate change have been recorded (Bayer, 2013; Chung et al., 2011; Comstock, 2011; Warren and Barnett, 2012).

To determine the extent to which higher educational institutions across the United States have incorporated issues related to climate change in horticultural classes and curricula, a survey of current instructors was conducted. Because little was known about the subject, the survey was designed to determine if and to what extent climate change information is being included within horticultural programs. The survey was not an in-depth inquiry 
into exactly what institutions or instructors are doing in regard to climate change instruction.

\section{Methods}

An online survey about teaching climate change or global warming in undergraduate classes related to horticulture was created. Survey items asked about climate change content in the curriculum, content in the courses the respondent taught, and changes in the content in those courses. Items covering basic demographics about the institution and the instructor were also included. The survey was designed to be short and quick to complete. Respondents were instructed to answer the questions off the top of their heads and not to spend time looking up any information, thus it is not an accurate survey of what is taught, but rather an indication of the instructor's perceptions of what is currently being taught at their institutions. Respondents were initially presented with a list of examples of class topics that might include discussion of climate change to show what was being addressed in the survey. Examples included water supplies for horticultural production, plant damage from extreme weather events, and the new USDA cold hardiness map. Because participants were told that the survey was about climate change, there is likely to be a bias in the respondents toward people who include the topic in their courses.

Names and e-mail addresses of instructors of undergraduate horticulture classes were obtained through web searches. Websites of land-grant schools (Association of Public and Land-grant Universities, 2012) were searched for programs or degrees related to horticulture or plant sciences. If any were found, the websites were further searched for the names of instructors associated with specific classes related to horticulture, including introductory horticulture, propagation, plant identification, and management or production classes such as arboriculture or olericulture. Contact information was obtained for up to three instructors per institution, depending on the ease of finding the information. If it was not relatively easy to identify the instructor of a specific course by name, the search was discontinued. To obtain information about non-land-grant schools, an Internet search was conducted with these terms: horticulture, major, and "university OR college." Websites for non-land-grant schools were searched in the order they appeared in the search and in the same manner as the land-grant sites. If three sites in the same state were found to teach horticulture, no further schools from that state were included. Requests to participate in the survey were e-mailed to 117 instructors at 90 different institutions. Completed surveys were received from 43 instructors (response rate of $37 \%$ ) in 38 institutions (42\%); this response rate is typical for this type of survey (Cook et al., 2000).

Statistical comparisons focused on the content related to climate change in any undergraduate course that was taught by the respondent and the change in that content over time. Respondents who said they included content were categorized based on their open-ended responses as either having minor or more than minor content. Those who listed multiple topics and topics that clearly related to climate change, such as carbon sequestration, were placed in the more than minor category. A similar break down was used to categorize respondents based on what they said they had changed over time. Those grouped in the minor category were combined with those who reported no content or change, leaving two categories for each question: "none or minor" and "more than minor." These categorizations were compared with other questions with categorical responses (e.g., are you tenured) using a $\chi^{2}$ statistic from two-way frequency tables and to the question with noncategorical responses (how many years have you been teaching) using analysis of variance. For this study, the type I error rate was set at 0.20 , because the consequences of incorrectly rejecting the null hypothesis (i.e., assuming that there is an association between a variable and climate change content when it does not actually exist) is relatively inconsequential, whereas overlooking a potential association that is real could lead to prematurely ignoring an important factor.

\section{Results and discussion}

Most respondents were from 1862 land-grant universities (65\%). Others were from 2 -year institutions (18\%), 4-year non-land grants (12\%), and
1890 land grants (5\%). They had been teaching for an average of 18 years (range $1-43$ years) and most were tenured at their current institutions $(70 \%)$. Some of these instructors had global warming content in classes they took when they were students (21\%).

Four survey items addressed the awareness of what was being taught within the respondents' departments to see how common climate change content might be in the horticultural curriculum in general. Most respondents $(82 \%)$ said they were not aware of courses taught in their unit with the terms "climate change" or "global warming" in the title or description (Table 1). Some (16\%) said "yes," indicating they believed such courses exist. Estimating the number of such courses from these responses appears to overstate their prevalence. A web search of the course titles and descriptions for the departments of those respondents who said "yes" and of random additional schools yielded only one course: Hort 3600: Climate Change and the Future of Food (Cornell University, 2013a). Perhaps more were not found because they are new classes that are not yet listed in online catalogs; more likely, some respondents were thinking of the content in a course rather than the title or description, because respondents were asked to answer without looking up the information. When asked if courses with "climate change" or "global warming" in the title or description were being prepared to offer in the future, $14 \%$ reported that such classes were in the pipeline. The accuracy of these responses is difficult to assess by reviewing websites, but given the likely overestimate on the previous question, and the small number of respondents who said "yes," it is likely that few classes with these terms in the title are being added. Although few classes use the term "climate change" in their titles or descriptions, many may include content related to climate change: more than half of the respondents $(61 \%)$ reported being aware of such content in courses taught by colleagues in their units. Finally, 9\% of respondents reported that their departments offered an undergraduate specialization or minor related to climate change. A follow-up web search yielded two minors with the phrase in the name: "Climate Change Minor" 
(Cornell University, 2013b) and "Climate Change and Energy Minor" (Utah State University, 2013). Other items asked about classes taught by other departments, partly to assess how much students might be learning about climate change from courses in other fields. Fewer than half of the respondents $(42 \%)$ reported being aware of courses related to climate change in other departments that their students could take as electives. Even more $(46 \%)$ said they did not know if this opportunity was available for their majors. Only $14 \%$ reported that their students were required to take a course related to climate change taught in a different department.

Respondents were asked if they included any content, even a minor amount, related to climate change or global warming in the classes that they taught. Nearly everyone (93\%) said they did (Table 2). This appears to indicate that discussion of climate change is prevalent in the horticultural curriculum; however, there is likely to be a bias toward instructors who include the topic among the respondents, because they would probably be more willing to complete the survey than instructors who do not include it. Examples of comments the respondents added when asked to explain their answer to this item included: "We talk about changes in weather patterns impacting not only the demand for various environmental tolerances, but the availability of resources such as water and energy," "Points related to global warming are addressed only several times... in very minor ways," and "We examine the effects of creating carbon sinks in the new urban environments that will dominate society by 2050 ."
Respondents were not asked specifically about the quantity of the climate change content they teach, but it was clear from their comments that it ranged from as little as part of one lecture to one-third of a course. When asked if the content related to climate change had changed over time, $81 \%$ said it had, and in all cases, the change was an increase (Table 2). Examples of their comments explaining how it had changed included: "This topic has changed from an ancillary, minor concept to one of considerable impact," "There are more data on topics relevant to horticulture, so we can discuss in more detail," "Once it was just mentioned, now it lasts a full lecture," and "Definitely increased as student interest in the topic has also increased."

Respondents were asked to describe the content related to climate

Table 1. Postsecondary horticultural instructors' responses on survey items regarding awareness of climate change content in the curriculum in their departments and in other departments at their institutions.

\begin{tabular}{|c|c|c|c|}
\hline \multirow[b]{2}{*}{ Survey item } & \multicolumn{3}{|c|}{ Response $^{\mathrm{z}}$} \\
\hline & Yes (\%) & No (\%) & Don't know (\% \\
\hline
\end{tabular}

About the instructor's department:

Are you aware of undergraduate courses in your department with climate change, global warming, or comparable terms in TITLE or description that are currently offered?

Are you aware of undergraduate courses in your department with climate change, global warming, or comparable terms in TITLE or description that are being prepared to offer in the future?

Are you aware of any CONTENT related to climate change or global warming in undergraduate courses that OTHER instructors in your department teach?

Does your department offer an undergraduate specialization or minor related to climate change or global warming?

$\begin{array}{llr}16 & 82 & 2 \\ 14 & 46 & 40 \\ 61 & 16 & 23 \\ 9 & 91 & 0 \\ 42 & & 46 \\ 14 & 46 & 40 \\ & & \end{array}$

About other departments in the school:

Are you aware of any undergraduate courses related to climate change or global warming and taught by other departments that undergraduate majors may take as electives?

Are you aware of any undergraduate courses related to climate change or global warming and taught by other departments that undergraduate majors are required to take?

${ }^{\mathrm{z}}$ Expressed as a percent of all 43 survey respondents.

Table 2. Coverage of climate change content and change in coverage over time in courses taught by postsecondary horticultural instructors.

\begin{tabular}{|c|c|c|c|}
\hline \multirow[b]{2}{*}{ Survey item } & \multicolumn{3}{|c|}{ Response category $^{\mathrm{z}}$} \\
\hline & None (\%) & Minor (\%) & More than minor (\%) \\
\hline $\begin{array}{l}\text { Is there any content related to climate change or global warming in any } \\
\text { undergraduate course that you teach? }\end{array}$ & 7 & 42 & 51 \\
\hline $\begin{array}{l}\text { Has content related to climate change or global warming in any } \\
\text { undergraduate course that you teach changed over time? }\end{array}$ & 19 & 44 & 37 \\
\hline
\end{tabular}

${ }^{\mathrm{z}}$ Expressed as a percent of all 43 survey respondents.

${ }^{y}$ For all instructors who reported a change, the change was an increase in content. 
change in their courses. The most common general topic reported was related to temperature effects and was included by $58 \%$ of the respondents (Table 3). For many, this was simply introducing the revised USDA hardiness zone map (Daly et al., 2012); heat injury is another example of what was included in this topic. Nearly half of the respondents (47\%) included topics related to water issues, such as flooding problems or irrigation needs. Issues specifically related to carbon dioxide, such as sequestration and carbon budgets, were included by $26 \%$ of the respondents.

Instructors who teach certain types of horticultural courses, such as commodity-based ones, were more likely to have incorporated climate change content than instructors who teach other courses. For example, 80\% of instructors who teach courses related to fruits or vegetables had incorporated more than minor climate change content, whereas only $42 \%$ of those who do not teach fruits or vegetables had done so (Table 4). Instructors in turf, landscape management, and plant identification also seem likely to have incorporated climate change content. Those who teach plant identification courses were also more likely to have increased the content related to climate change than those who teach other courses, with $44 \%$ of plant identification instructors reporting more than minor increase and only $25 \%$ of those who do not teach it doing so.

The demographic factor most associated with having more than minor content related to climate change in a course was teaching at a non-1862 land-grant school, with $67 \%$ of them having incorporated it, but only $43 \%$ of instructors at 1862 land-grants had done so (Table 5). Instructors without tenure were also more likely to have increased climate change content than those with tenure $(54 \%$ and $30 \%$, respectively). The number of years teaching was not related to either having more than minor content or having made more than a minor increase in content over time (data not shown).

Respondents were asked to comment on whether they thought content related to climate change should be increased in horticulture classes. Examples of responses were: "It's hard to imagine that climate change

Table 3. General instructional topic areas related to climate change taught in postsecondary horticultural courses, listed in order by the percent of instructors who teach them.

\begin{tabular}{lc}
\hline General topic areas covered in courses & $\begin{array}{c}\text { Instructors who } \\
\text { teach topic (\%) }\end{array}$ \\
\hline Temperature (e.g., U.S. Department of & 58 \\
Agriculture hardiness map, heat injury) & \\
Water (irrigation, drought, flooding) & 47 \\
Plant selection, placement, or timing & 33 \\
Weather pattern changes or monitoring & 33 \\
Carbon dioxide (cycle, budgets, levels, sequestration) & 26 \\
Pests (insects, diseases, weeds) & 21 \\
Ecosystem services (e.g., storm-water, heat island) & 21 \\
Other (phenology, stresses, biodiversity, & $9-14($ each) \\
greenhouse management, energy use) & \\
\hline${ }^{2}$ Expressed as a percent of all 43 survey respondents.
\end{tabular}

${ }^{2}$ Expressed as a percent of all 43 survey respondents.

Table 4. Number of postsecondary horticultural instructors who teach different types of horticulture courses, proportion of the instructors of a specific course type who include more than minor content on climate change, proportion of the instructors of a specific course type have made more than a minor increase in climate change coverage over time, and comparisons to instructors who do not teach in those courses.

\begin{tabular}{|c|c|c|c|c|c|}
\hline \multirow[b]{2}{*}{ Course } & \multirow{2}{*}{$\begin{array}{c}\text { Instructors } \\
\text { (no.) }\end{array}$} & \multicolumn{2}{|c|}{$\begin{array}{l}\text { Proportion with } \\
\text { more than minor } \\
\text { content }\end{array}$} & \multicolumn{2}{|c|}{$\begin{array}{c}\text { Proportion who made } \\
\text { more than a minor } \\
\text { increase }\end{array}$} \\
\hline & & $(\%)^{\mathrm{z}}$ & $P^{\mathrm{y}}$ & $(\%)^{\mathrm{z}}$ & $P^{\mathbf{y}}$ \\
\hline \multicolumn{6}{|c|}{ Plant identification } \\
\hline Teach & 27 & 59 & 0.17 & 44 & 0.20 \\
\hline Don't teach & 16 & 38 & & 25 & \\
\hline \multicolumn{6}{|c|}{ Introductory horticulture } \\
\hline Teach & 26 & 54 & ns & 38 & ns \\
\hline Don't teach & 17 & 47 & & 35 & \\
\hline \multicolumn{6}{|c|}{ Landscape management } \\
\hline Teach & 23 & 61 & 0.17 & 39 & ns \\
\hline Don't teach & 20 & 40 & & 35 & \\
\hline \multicolumn{6}{|c|}{ Nursery or greenhouse } \\
\hline Teach & 22 & 45 & ns & 32 & ns \\
\hline Don't teach & 21 & 57 & & 43 & \\
\hline \multicolumn{6}{|l|}{ Propagation } \\
\hline Teach & 18 & 56 & ns & 39 & ns \\
\hline Don't teach & 25 & 48 & & 36 & \\
\hline \multicolumn{6}{|l|}{ Arboriculture } \\
\hline Teach & 14 & 57 & ns & 36 & ns \\
\hline Don't teach & 29 & 48 & & 38 & \\
\hline \multicolumn{6}{|c|}{ Fruits or vegetables } \\
\hline Teach & 10 & 80 & 0.04 & 40 & ns \\
\hline Don't teach & 33 & 42 & & 36 & \\
\hline \multicolumn{6}{|l|}{ Turf } \\
\hline Teach & 9 & 78 & 0.07 & 33 & ns \\
\hline Don't teach & 34 & 44 & & 38 & \\
\hline
\end{tabular}

$\mathrm{ns}=$ probability of significant difference is greater than 0.20 .

${ }^{2}$ Expressed as a percent of instructors who do or do not teach the specific course.

"Probability that the proportion of instructors of a specific course who have included climate change content or have increased such content is significantly different from the proportion of instructors who do not teach the course, based on a $\chi^{2}$ test.

shouldn't relate to almost every course in Horticulture," "Absolutely! Horticulturists along with farmers have to deal with the effects of weather and climate every day and it's getting more complicated," and "Depends upon the class...can have major bearing on the class or little impact." 
Table 5. Number of instructors in different demographic categories, proportion of instructors in a single demographic who include more than minor content on climate change, proportion of instructors in a single demographic who have made more than a minor increase in climate change coverage over time, and comparisons to instructors who are not in the same demographic.

\begin{tabular}{|c|c|c|c|c|c|}
\hline \multirow[b]{2}{*}{ Course } & \multirow{2}{*}{$\begin{array}{l}\text { Instructors } \\
\text { (no.) }\end{array}$} & \multicolumn{2}{|c|}{$\begin{array}{l}\text { Proportion with } \\
\text { more than minor } \\
\text { content }\end{array}$} & \multicolumn{2}{|c|}{$\begin{array}{l}\text { Proportion who made } \\
\text { more than a minor } \\
\text { increase }\end{array}$} \\
\hline & & $(\%)^{\mathrm{z}}$ & $P^{\mathbf{y}}$ & $(\%)^{\mathrm{z}}$ & $P^{y}$ \\
\hline \multicolumn{6}{|c|}{ At an 1862 land-grant school } \\
\hline Yes & 28 & 43 & \multirow[t]{2}{*}{0.14} & 36 & \multirow[t]{2}{*}{ ns } \\
\hline No & 15 & 67 & & 40 & \\
\hline \multicolumn{6}{|c|}{ At a 2 -year school } \\
\hline Yes & 13 & 62 & \multirow[t]{2}{*}{ ns } & 38 & \multirow[t]{2}{*}{ ns } \\
\hline No & 30 & 47 & & 37 & \\
\hline \multicolumn{6}{|c|}{ With tenure } \\
\hline Yes & 30 & 50 & \multirow[t]{2}{*}{ ns } & 30 & \multirow[t]{2}{*}{0.14} \\
\hline No & 13 & 54 & & 54 & \\
\hline \multicolumn{6}{|c|}{ Received instruction in climate change } \\
\hline Yes & 9 & 44 & \multirow[t]{2}{*}{ ns } & 22 & \multirow[t]{2}{*}{ ns } \\
\hline No & 34 & 53 & & 41 & \\
\hline
\end{tabular}

ns = probability of significant difference is greater than 0.20 .

${ }^{2}$ Expressed as a percent of instructors who are in the same specific demographic.

y Probability that the proportion of instructors within a demographic who have included climate change content or have increased such content is significantly different from the proportion of instructors not in that demographic, based on a $\chi^{2}$ test.

\section{Conclusion}

The results of this study show that some instructors in the United States are clearly concerned about the impacts of climate change and global warming on horticulture, and they have made major changes in what they teach. Many others are beginning to touch on issues related to climate change, but only to a minor degree. If such content is to increase, climate change literacy among our instructors may need to be facilitated, as only $21 \%$ reported having learned about it in the classes they took as students.

Although some content on climate change and global warming is being incorporated into horticulture classes, institutions are not letting potential students know that climate change is part of the horticulture curriculum, as the terms are rarely used in course titles or descriptions. With content on climate change increasing in $\mathrm{K}-12$ school standards (Achieve, 2013), future students will be more knowledgeable about the subject when they enter postsecondary schools. Letting potential students know that they will be learning about this critical topic in our curricula could become a factor in recruiting the best and the brightest students into our horticulture-related majors.
Predicted changes in the global climate will have major negative impacts on horticultural crops (Battisti and Naylor, 2009; Karl, 2009; Walthall et al., 2013). What students need to understand to live and work under such drastically changing conditions is very different from what students in previous decades were taught. Increasing climate change content in our courses is imperative.

\section{Literature cited}

Achieve. 2013. Next Generation Science Standards: For States, By States. 17 Oct. 2013. <http://www.nextgenscience. org/>.

Association of Public and Land-grant Universities. 2012. The Land-Grant Tradition. 26 May 2013. <http://www.aplu. org/document.doc?id=780>.

Augspurger, C.K. 2013. Reconstructing patterns of temperature, phenology, and frost damage over 124 years: Spring damage risk is increasing. Ecology 94:41-50.

Basinger, A.R., C.B. McKenney, and D. Auld. 2009. Competencies for a United States horticulture undergraduate major: A national Delphi study. HortTechnology 19:452-458.

Battisti, D.S. and R.L. Naylor. 2009. Historical warnings of future food insecurity with unprecedented seasonal heat. Science 323:240-244.
Bayer, A. 2013. Using Different Teaching Methods to Enhance Student Learning of Climate Change. 17 Oct. 2013. <http:// ashs.org $/ \mathrm{db} /$ horttalks $/$ detail.lasso? $\mathrm{id}=$ $15582>$.

Booth, E.L.J., J.M. Byrne, and D.L. Johnson. 2012. Climatic changes in western North America, 1950-2005. Intl. J. Climatol. 32:2283-2300.

Chung, U., L. Macj, J.I. Yun, and S.H. Kim. 2011. Predicting the Timing of Cherry Blossoms in Washington, DC and Mid-Atlantic States in Response to Climate Change. 17 Oct. 2013. <http:// ashs.org/db/horttalks/detail.lasso?id= $116725>$.

Comstock, J.P. 2011. Phenology Modeling and Frost Risk Assessment with Climate Change for Temperate Fruit Crops. 17 Oct. 2013. <http://ashs.org/db/ horttalks $/$ detail.lasso?id=116774 $>$.

Cook, C., F. Heath, and R.L. Thompson. 2000. A meta-analysis of response rates in web- or internet-based surveys. Educ. Psychol. Meas. 60:821-836.

Cornell University. 2013a. Courses of Study: Horticulture Courses. 29 Sept. 2013. <http://courses.cornell.edu/ preview_program.php? catoid $=18 \&$ poid $=$ $7836>$.

Cornell University. 2013b. Climate Change Minor. 6 Oct. 2013. <http:// courses.cornell.edu/preview_program.php? catoid $=18 \&$ poid $=8194>$.

Daly, C., M.P. Widrlechner, M.D. Halbleib, J.I. Smith, and W.P. Gibson. 2012. Development of a new USDA plant hardiness zone map for the United States. J. Appl. Meteorol. Climatol. 51:242-264.

Karl, T.R., J.M. Melillo, and T.C. Peterson (eds.). 2009. Global Climate Change Impacts in the United States. 19 Dec. 2011. <http://downloads.globalchange.gov/ usimpacts/pdfs/climate-impactsreport.pdf>.

Lyall, S. 2013. Heat, Flood or Icy Cold, Extreme Weather Rages Worldwide. 1 Oct. 2013. <http://www.nytimes.com/ 2013/01/11/science/earth/extremeweather-grows-in-frequency-and-intensityaround-world.html? pagewanted=all\& $\_r=0>$.

Marino, G.P., D.P. Kaiser, L. Gu, and D.M. Ricciuto. 2011. Reconstruction of false spring occurrences over the southeastern United States, 19012007: An increasing risk of spring freeze damage? Environ. Res. Lett. 6:024015.

McGowan, M. 2013. Sustainability leaders Outline Local Climate Change 
Impact. 1 Oct. 2013. <http://www. thetimesnews.com/news/top-news/ sustainability-leaders-outline-local-climatechange-impact-1.197517>.

National Oceanic and Atmospheric Administration. 2013. State of the Climate. 27 June 2013. <http://www.ncdc.noaa. gov $/$ sotc $>$.

Pritts, M.P. and T. Park. 2013. Proposed learning outcomes for four-year horticulture programs in the United States. HortTechnology 23:237-240.

USA National Phenology Network. 2013. Resources for Higher Education. 26 June 2013. <https://www.usanpn. org/education/higher $>$.

U.S. Environmental Protection Agency. 2013a. Climate Change Indicators in the United States: Length of Growing Season. 1 Oct. 2013. <http://www.epa.gov/ climatechange/science/indicators/societyeco/growing-season.html>.
U.S. Environmental Protection Agency. 2013b. Climate Change Indicators in the United States: U.S. and Global Precipitation. I Oct. 2013. <http://www.epa. gov/climatechange/science/indicators/ weather-climate/precipitation.html>.

U.S. Environmental Protection Agency. 2013c. Climate Change. 1 Oct. 2013. <http://www.epa.gov/climatechange>.

U.S. Global Change Research Program. 2009. Climate Literacy: The Essential Principles of Climate Science. 19 Dec. 2011. <http://library.globalchange. gov/downloads/download.php?id=126>.

Utah State University. 2013. Climate Change and Energy Minor. 6 Oct. 2013. <http://catalog.usu.edu/preview_program. php? catoid $=7 \&$ poid $=3701 \&$ hl $=\% 22$ minor $\%$ 22\&returnto=search $>$.

Walthall, C.L., J. Hatfield, P. Backlund, L. Lengnick, E. Marshall, M. Walsh, S. Adkins, M. Aillery, E.A. Ainsworth, C. Ammann, C.J. Anderson, I. Bartomeus,
L.H. Baumgard, F. Booker, B. Bradley, D.M. Blumenthal, J. Bunce, K. Burkey, S.M. Dabney, J.A. Delgado, J. Dukes, A. Funk, K. Garrett, M. Glenn, D.A. Grantz, D. Goodrich, S. Hu, R.C. Izaurralde, R.A.C. Jones, S-H. Kim, A.D.B. Leaky, K. Lewers, T.L. Mader, A. McClung, J. Morgan, D.J. Muth, M. Nearing, D.M. Oosterhuis, D. Ort, C. Parmesan, W.T. Pettigrew, W. Polley, R. Rader, C. Rice, M. Rivington, E. Rosskopf, W.A. Salas, L.E. Sollenberger, R. Srygley, C. Stöckle, E.S. Takle, D. Timlin, J.W. White, R. Winfree, L. Wright-Morton, and L.H. Ziska. 2013. Climate change and agriculture in the United States: Effects and adaptation. U.S. Dept. Agr. Tech. Bul. 1935.

Warren, P. and L.A. Barnett. 2012. Train Extension Volunteers to Track Climate Change by Monitoring Phenology. 26 June 2013. <http://ashs.org/db/horttalks/ detail.lasso? $\mathrm{id}=11554>$. 